Research, part of a Special Feature on Navigating Trade-offs: Working for Conservation and Development Outcomes

\title{
City Life in the Midst of the Forest: a Punan Hunter-Gatherer's Vision of Conservation and Development
}

\author{
$\underline{\text { Patrice Levang }}^{1}, \underline{\text { Soaduon Sitorus }}^{2}{ }^{\text {and Edmond Dounias }}{ }^{1}$
}

\begin{abstract}
The Punan Tubu, a group of hunter-gatherers in East-Kalimantan, Indonesia, are used to illustrate the very real trade-offs that are made between conservation and development. This group has undergone various forms of resettlement in the $20^{\text {th }}$ century, to the point that some are now settled close to the city of Malinau whereas others remain in remote locations in the upper Tubu catchment. This study is based on several years of ethnographic and household analysis. The Punan clearly favor both conservation and development. In the city, the Punan benefit from all positive effects of development. Child and infant mortality rates are very low, and illiteracy has been eradicated among the younger generation. However, the Punan complain that nothing in town is free. The older generation, in particular, resents the loss of Punan culture. Because of frustration and unemployment, young people often succumb to alcoholism and drug addiction. The Punan do not want to choose between conservation and development, between forest life and city life. They want to benefit from the advantages of both locations, to enjoy both free forest products and the positive aspects of modern life, to go wild boar hunting in the morning and watch television in the evening. In short, they want to enjoy city life in the midst of the forest. The same kind of contradiction has led to identity problems. They want to uphold the traditional life of the hunter-gatherer, but at the same time they reject marginalization and seek integration into the larger society. In short, they want integration without loss of identity. The settlement of Sule-Pipa illustrates how some groups have dealt with the contradiction more successfully. Thanks to good organization and charitable donations, they have secured educational facilities and basic health care, and marketing costs are reduced by collectively organized road and river transportation. The economy of the village is thriving, mainly because of the collection of forest products from the primary forest. Remoteness has saved the community from intensive logging, from uncontrolled and excessive exploitation of local forest products by outsiders, and from forest conversion. But few remote communities enjoy the luxury of charitable injections of funds, and roads will be built to the remote locations sooner or later. However, playing for time can help the Punan develop the capacity and ability to cope with a competitive developed world and maintain their cultural identity.
\end{abstract}

Key Words: Borneo; conservation and development trade-offs; hunter-gatherers; Indonesia; modernization; resettlement; Punan

\section{INTRODUCTION}

The destruction of forests is continuing at unprecedented rates, bringing about wholesale changes to landscapes, loss of biodiversity, and often, the long-term ruin of some people's livelihoods. Others benefit sufficiently, however, to maintain the pressure on forests. Initial optimism about the potential to achieve both forest protection and livelihood improvement through integrated conservation and development has been tempered by a recognition that trade-offs are necessary (Sayer and Campbell 2004). Natural "win-win" situations in tropical forests, in which both conservation and development objectives are met, are more often the exception than the rule. Local people usually clear forests because it pays them to do so ("lose-win"), whereas forest protection may be at the expense of foregoing local welfare gains ("win-lose"). Under what circumstances is it possible to reconcile conservation and development objectives in forested landscapes? What needs to be done to 
create the appropriate conditions in this regard? We examine these questions from the perspective of the Punan Tubu, a group of hunter-gatherers ${ }^{\mathrm{a}}$ formerly living in the Tubu watershed, a tributary of the Mentarang River, in the district of Malinau (East Kalimantan). The Punan Tubu deserve particular attention as they form the largest concentration of Punan in one place in East Kalimantan. Since 1996, a large amount of scientific literature on Punan and Dayak groups of the same area has been made available by the World Wildlife Fund (WWF; now known as the World Wide Fund for Nature) (Kayan Mentarang National Park) and CIFOR (Malinau Research Forest). The Punan Tubu are not alone in experiencing adaptation problems to a more sedentary and urban way of life. Similar problems have been recorded with Penan groups from Sarawak (Pritchard 2005).

Most of the Punan Tubu were still nomadic at the beginning of the $20^{\text {th }}$ century (Harrisson 1986); the bands starting to settle in more or less permanent villages when they decided to take up swidden cultivation. Nowadays, all Punan reside in villages, but the families living in small hamlets on the upper reaches of the Tubu River are still highly mobile, and could be classified as semi-nomadic. According to a census carried out in 2002-2003 (Sitorus et al. 2004), 89\% of all Punan households of East Kalimantan regularly practiced swidden cultivation. Some families may skip agricultural activities for a year in order to focus on collecting forest products. Some scholars argue that these recent swidden cultivators can no longer rightly be called huntergatherers. For the purposes of our research, as most of the Punan still devote more time to hunting and gathering than to agriculture, and as forest products make up the bulk of household income, they still differ from Dayak who are long-settled agriculturists who only occasionally go on a collection tour. Furthermore, the Punan clearly have a hunter-gatherer ideology that is the basis of their cultural identity. About 13 Punan villages, each consisting of 15 to 25 households, were officially recorded in the Tubu watershed at the end of the 1960s. During the early 1970s, the Indonesian government decided to resettle remote villages to more accessible areas downstream. Being unable to bring development to the remotest areas of the province and wanting greater social control, the government decided to move the forest people closer to civilization. Eight Tubu villages were resettled in Respen Sembuak, ${ }^{b}$ close to the city of Malinau. A certain degree of coercion was exerted; even so, five villages managed to stay in the upper Tubu. Thirty years later, the two groups had evolved in quite different ways. In Respen Sembuak, the Punan families have good access to major services, such as formal education, health care, markets for goods and labor, leisure activities, etc. In contrast, little has changed since the 1970s in the upper Tubu. Despite the widespread use of long-tail boat engines, which have made transportation much easier, it still takes at least 4 to 6 days by canoe and on foot to reach the remotest villages. The settlements have no electricity, no dispensaries, no rice mills, and no trading posts. Schools open from time to time, but teachers seldom stay for more than a few months.

The comparison between the upstream and downstream Punan Tubu groups is of utmost interest. The two populations have the same origin, belong to the same ethnic group, and have the same language and culture. Of course, some minor differences exist between sub-groups. These differences are generally linked to diverging histories of contact and relations with different neighbors (Kaskija 1999, 2002, Sellato 2001). These differences seem minor, however, and as such do not affect our comparison. The groups are not isolated from each other. Upstream and downstream households have strong family bonds, and visit each other from time to time. Some families have even moved from one location to the other from time to time. But, in general, the two populations have been living in very different environments for over 30 years, and have developed different ways of living, with different livelihood options, diverging diet and health status, and contrasting perceptions and opinions about conservation and development.

This work is based on 5 years of ethnographic and household analyses of the Punan Tubu. The work covered household economics, health and nutrition, and other aspects of human wellbeing. The surveys were conducted in collaboration with the Association of Punan Communities (Yayasan Adat Punan).

\section{PROS AND CONS OF LIVING IN AND OUT OF THE FOREST}

Generally accepted ideas about living in the city or in the forest can be quite contradictory. In developing countries, where the rural exodus is still a recent phenomenon, local people generally favor 
moving out of the forest in order to secure improved livelihoods (e.g., Campbell et al. 2002). Moreover, the trend in household livelihood strategies is toward more diversified, off-farm activities (Ellis 2000, Rigg 2006). Off-farm income and remittances from the cities where family members are working are becoming increasingly important for rural households. In contrast to this perspective, the myth of the noble savage is still very much alive, and it is widely accepted, mainly by people in developed countries, that the only place where forest people can live a decent life - in harmony with nature, and practicing ancestral customs - is deep within the forest. The Punan do not prefer life in the forest over life in the city: they clearly want both conservation and development. When questioned about the role and importance of forests, they can talk at length about the cultural, social, economic, and esthetic values associated with the forest. And, when questioned about the forest products that matter to them, they can draw up endless lists of animals and plants they commonly eat, use, barter, sell, or worship (Sheil et al. 2002; Sheil and Wunder 2002). Consequently, some romantic anthropologists (and conservationists) often invest forest people with conservation goals and want to turn them into guardians of the forest (Bunyard 1989, Forest Trends 2002). And yet, the same Punan warmly welcome any timber baron offering them royalties of US\$5-10 per cubic meter of timber extracted from their "beloved forests" (Levang et al. 2005a). When queried as to whether they really want to conserve the forest, they argue that they need money to make a better living, send their children to school, pay for health care, pay expensive bride prices, and buy boat engines, chain saws, televisions, and video players.

In order to clarify the trade-offs that exist between conservation and development, we surveyed residents of both the upper Tubu and Respen Sembuak. As the Punan Tubu in the former location live in a well-forested environment, they might be expected to have a better understanding of the advantages of conservation and the disadvantages of living far from any development. The Punan in Respen, however, might have better insight into the positive and negative aspects of development. Initially, in each location, groups of young, middleaged, and old males and females were asked to identify and rank what they considered to be advantages and disadvantages of living in their present location. In each location, most advantages and disadvantages were put forward by all those surveyed, and they soon reached a consensus. Some criteria were put forward only by a specific sex or age group, but were not dismissed by the other subgroups. Only very few criteria generated controversy, e.g., when a teenager saw the loss of Punan culture as an advantage, linking it to less parental control over premarital intermingling. Eleven positive and nine negative criteria were finally selected in Respen Sembuak, and 11 positive and 13 negative criteria in the upper Tubu (Sitorus et al. 2004, Levang et al. 2005b).

Subsequently, a follow-up survey was conducted with 116 villagers in Respen and 81 villagers in the upper Tubu. Each participant was given cards summarizing all the identified criteria and was then asked to pick the three advantages and disadvantages that they considered to be most important. Everyone was free to decide whether a criterion was positive or negative. Only those criteria with more than $20 \%$ of the votes in each location were retained thereafter (Table 1).

\section{Positive Aspects of Living in Town}

\section{Access to health services}

Good access to health services was considered the most positive aspect of living close to the city of Malinau (76\% of votes) by both men and women. Lack of health care was also put as the main disadvantage $(67 \%)$ of living in the middle of the forest. This result does not come as a surprise considering the health situation prevailing in the remotest areas of the Tubu. Until recently, no medical doctors or paramedics had ever visited the area ${ }^{\mathrm{c}}$ there are no drugstores, medicine is in short supply everywhere, ${ }^{\mathrm{d}}$ and when by chance medicine is available, self-medication is the rule. ${ }^{e}$ Going downriver, Malinau can be reached in a day. However, river transportation takes much more time when water levels are too low, and is very risky when the flow is too strong; both of which happen quite frequently. Furthermore, in villages accessible only by foot, it is not feasible to transport sick people.

Previous studies have shown extremely high child and infant mortality rates in the most remote settlements of East Kalimantan (Levang et al. $2005 \mathrm{~b}$; the average child and infant mortality rate is $36 \%$ in very remote areas, $27 \%$ in remote areas, 
Table 1. Results of a survey concerning the pros and cons of living in and out of the forest

\begin{tabular}{|c|c|c|c|}
\hline Living in the forest (Upper Tubu) & & Living out of the forest (Respen Sembuak) & \\
\hline Positive & & Positive & \\
\hline Forest products for food & $77 \%$ & Access to dispensary & $76 \%$ \\
\hline Land for swidden cultivation & $65 \%$ & Access to education & $58 \%$ \\
\hline Forest products for material & $55 \%$ & Access to information & $37 \%$ \\
\hline Forest products for cash & $21 \%$ & Work opportunities & $33 \%$ \\
\hline \multirow[t]{3}{*}{ Sharing / mutual work } & $20 \%$ & Electricity & $26 \%$ \\
\hline & & Transportation & $25 \%$ \\
\hline & & Rice mills & $22 \%$ \\
\hline Negative & & Negative & \\
\hline No health care & $67 \%$ & Lack of security & $62 \%$ \\
\hline Basic goods expensive & $59 \%$ & Drugs and alcohol & $54 \%$ \\
\hline Poor accessibility & $41 \%$ & Loss of Punan culture & $46 \%$ \\
\hline No rice mill available & $33 \%$ & Lack of access to agricultural land & $35 \%$ \\
\hline \multirow[t]{3}{*}{ No government subsidies } & $31 \%$ & Competition with other groups & $29 \%$ \\
\hline & & Weakening of customary rules & $22 \%$ \\
\hline & & No forest products for food & $22 \%$ \\
\hline
\end{tabular}

and $7 \%$ in accessible areas). In the absence of vaccination campaigns, inhabitants in these remote settlements are poorly immunized, and erratic and unpredictable epidemics of infectious or parasitic diseases (malaria, measles, hepatitis) take a heavy toll, especially among the youngest generation. Life expectancy is also quite short, with less than $2 \%$ of the population over 65 years of age. However, differences between remote and more accessible areas are not significant. Additional surveys carried out in the upper Tubu showed that the higher mortality rates were not caused by a less healthy environment, but by the lack of health services. Paradoxically, it is the reduced exposure to pathogens that is responsible for the children's low immune defence system. Pathogens are usually introduced upstream by outsiders or by insiders coming back from work migrations to Malaysian logging companies or plantations (Knapen 1998, Dounias et al. 2004). Most children fall victim to the secondary symptoms of the disease or to delayed over-infectious syndromes. As they cannot be put on a drip, high fever often causes lethal dehydration.

\section{Access to formal education}

Access to formal education in Respen Sembuak is regarded as the second most important advantage $(58 \%)$, with no difference in opinion between males and females. Surprisingly, lack of education is seldom mentioned as a problem in the upper Tubu, and yet previous studies have clearly shown the very 
high illiteracy levels in the remotest settlements, especially among women (Sitorus et al. 2004; Table 2). In Respen Sembuak, illiteracy has been wiped out among the younger generation. All children go to primary school, and more than half of them, both male and female, continue on to secondary school. Only a very few go on to post-secondary education, because of the high costs associated with staying in the more distant towns of Tarakan and Samarinda. In Respen Sembuak, nobody doubts that better education is the key to better integration, better jobs, and better positions. However, although they are well educated, the Punan generally lack the social connections needed to be recruited as civil servants or company employees. This situation frustrates young Punan graduates, and given the high costs involved, many parents are increasingly reluctant to send their children to university.

In the upper Tubu, in the absence of educational facilities, most parents are not willing to send their children to school in far-away villages, both for sentimental and economic reasons. Additionally, it is thought that formal education is of little help in the middle of the forest as there is no competition for jobs with other ethnic groups. Being a good hunter or eaglewood collector brings in more benefits. But, by not sending their children to school, many villagers are restricting their children's opportunities, forcing them to remain as huntergatherers.

\section{Access to information and job opportunities}

Access to information and job opportunities, respectively, come third (37\%) and fourth (33\%) among the advantages listed in Respen Sembuak, although they are seldom mentioned as positive or negative criteria in the upper Tubu. The two criteria are considered more important by men than women. People in Respen Sembuak have access to extensive information through the media (newspapers, radio, television) and through regular and direct contact with local authorities, numerous visitors, traders and investors, non-govermental organizations (NGOs), and research bodies. They have long known that the outside world makes decisions that directly or indirectly concern them, and that it is better to be aware of this in order to make the best of it.

In the upper Tubu, hunting and gathering are the only opportunities at hand. In Respen Sembuak, there are more opportunities than people willing to seize them. The Punan usually choose the opportunities providing the highest and quickest returns on labor. Short-term jobs are generally preferred, as long-term investments might prevent them from seizing better future opportunities. Salaried jobs as civil servants or company workers are much sought after, but for various reasonsincluding lack of training or education, lack of family and ethnic networks, and real or perceived poor work habits - the Punan are rarely selected for them. Even when engaged in a full-time job, a Punan has difficulty turning down a friend's hunting proposal.

\section{Access to other facilities: transportation,} electricity, rice mills, and leisure activities

Since the bridge over the Sesayap river was built and the road to Malinau was paved, the people of Respen have benefited from easier, cheaper, and safer means of transportation to the city's facilities by minibus or motorcycle taxis. Electricity and rice mills were also often cited as advantages of living in the city, especially by women. Surprisingly, leisure opportunities were rarely cited as an advantage of living in the city, even by the younger generation. People in the upper Tubu complain about transportation problems $(41 \%)$ to and from their villages, due to a very limited number of canoes equipped with long-tail engines, the excessive cost of boat renting, rare visits by traders, and the excessive price of basic goods $(59 \%)$ linked to high transportation costs. It is likely that this problem has been exacerbated since the price of fuel doubled at the end of 2005 .

The absence of rice mills was more often cited by women than by men in the upper Tubu. Quite surprisingly, the absence of electricity was put forward only very rarely. The absence of leisure opportunities was considered a problem by only $18 \%$ of the respondents, but by a significantly higher percentage of young men.

\section{Negative Aspects of Living in Town}

Most negative aspects cited by the Punan in Respen Sembuak are not directly linked to development aspects or to urban life, but more precisely to living in the town of Malinau, to their problematic relationships with other ethnic groups in the area, and to a lesser extent, to longer-term sociocultural changes among the Punan community. 
Table 2. Illiteracy rates according to accessibility

\begin{tabular}{lccc}
\hline \hline Location & $\begin{array}{c}\text { Males } \\
(\%)\end{array}$ & $\begin{array}{c}\text { Females } \\
(\%)\end{array}$ & $\begin{array}{c}\text { Total } \\
(\%)\end{array}$ \\
\hline Very remote & 54.9 & 76.7 & 65.8 \\
Remote & 33.5 & 48.9 & 40.9 \\
Accessible & 16.8 & 29.9 & 23.3 \\
& & & \\
\hline
\end{tabular}

\section{Lack of security}

The lack of security was voiced as a negative aspect by $62 \%$ of the population, irrespective of sex. Mingling with other ethnic groups does not always foster integration. Punan often feel marginalized ${ }^{f}$ and despised. In the worst cases, they become the whipping boys of some Malinau hoodlums. With the rapid development of the city of Malinau, and the construction of the bridge over the Sesayap River, Respen Sembuak has become a Malinau suburb and the price of land has soared. As a result, the Punan have been offered high prices for their land or have been harassed in order to make them leave. Quite often, individuals from the Tidung ethnic group, the traditional owners of the resettlement area, have made aggressive claims to regain the land that was given to the Punan by the government at a time when the land had no value. Formal complaints lodged by the Punan are usually not taken seriously by the police or the authorities because the perpetrators of this harassment are politically influential at the district level.

\section{Drugs and alcohol}

Drugs and alcohol are considered a problem by $54 \%$ of the population of Respen Sembuak, irrespective of sex. The percentage is much higher among the younger generation, who list it as the major disadvantage (by $83 \%$ of males and $67 \%$ of females). Various kinds of drugs and alcoholic drinks are popular among teenagers, and seemingly easy to find in Malinau. Cases of involuntary drug intake mixed with alcoholic drinks followed by robbery or rape have also been reported. The sale of alcoholic drinks is prohibited by the authorities of the district of Malinau, but is still tolerated in the numerous brothels that flourish near the city, tapping into the wages of concession workers. The risk of passing on sexually transmitted diseases to occasional clients, including Punan eaglewood collectors, is taken seriously by the local health services.

\section{Loss of Punan culture and weakening of customary rules}

The loss of Punan culture is perceived as a disadvantage of city life by $46 \%$ of the respondents in Respen Sembuak. However, during focus group discussions, we could never reach a consensus on what was meant by Punan culture, what differentiated the Punan from other groups. When asked what they actually lost, our respondents generally gave examples that clearly originated from neighboring groups. Until the $1960 \mathrm{~s}$, the Punan were exploited by their Dayak neighbors. Cultural differences between Punan groups are usually due to contacts and bonds with different Dayak groups. Over time, the Punan assimilated and appropriated some cultural elements from their Dayak masters. Nowadays, quite paradoxically, the Punan Tubu deny the Dayak origin of these cultural elements. In order to maintain a distinct identity, they have chosen not to become Dayak. They wish to conserve a distinct Punan hunter-gatherer ideology and social system, rather than just being second-rate Dayaks. Such feelings are especially strong in Malinau, where the Punan are daily confronted by other ethnic groups, such as the Kenyah or Lundaye, who have managed to retain many features of their strong traditional culture (dances, songs, outfits, woodcarving, etc.). In 
comparison, the Punan are considered to have little to offer, and they are seldom represented at cultural performances organized by the district (Independence Day, official visits, etc.). It should be noted that loss of culture is equally a problem in the upper reaches of the Tubu. For example, the most famous blowpipe manufacturers and traditional healers are found in Respen Sembuak and not in the upper Tubu. It was in Respen Sembuak that the Yayasan Adat Punan (Association of Punan Communities) was founded with the mission to preserve the Punan identity. The weakening of customary rules is resented (22\%) in Respen Sembuak, although less so by younger males. It was never cited as problem in the upper Tubu. When queried about which customary rules were weakening in the city, elder people generally complained about the disrespectful behavior of the younger generation, and more specifically, about their boundless promiscuity. The younger Punan kept silent. But the most resented change is, without doubt, the disappearing value of sharing, especially of wild boar (see below).

\section{Lack of access to agricultural land}

Lack of access to agricultural land in Respen Sembuak was listed as a disadvantage by $35 \%$ of respondents, but with very different scores according to age group and sex. Younger men are unconcerned $(0 \%)$ whereas older men consider it a major problem $(62 \%)$. When the older age group was resettled in Malinau in the 1970s by the government, they cleared old secondary forest in order to establish swiddens and plantations. Nowadays, because of the tremendous development in the city of Malinau, the price of land has reached unprecedented heights. Consequently, the Tidung have forbidden any new clearing and have even asked that the current plots be returned. The younger generation is less interested in opening new swiddens, preferring paid employment or to make do with the plots acquired by their fathers.

In the upper Tubu, however, large areas of land for swiddens are available, free of competing claims. This opportunity is considered as a major advantage to living in the forest $(65 \%)$. It even ranks first (91\%) for men aged 20-40.

\section{Competition with other groups}

Competition with other ethnic groups is a daily problem for all suburban Punan (29\%), especially the younger generation (42\%). Competition for local opportunities is high. Kenyah, Lundaye, and Tidung get nearly all the jobs in the local administration. Migrants with higher qualifications are preferred by private companies for the betterpaid jobs. Migrants lacking specific qualifications are also preferred for labor-intensive work. ${ }^{\mathrm{g}}$ The Punan community counts only a few skilled craftsmen, and these are regularly passed over during invitations to tender because of their reputation of having a poor work ethic. The only fields where the Punan predominate are hunting and gathering, and the younger generation, educated in the city, lack this ability.

\section{No forest products for food}

About $22 \%$ of the Punan, especially the women $(30 \%)$, resent the fact that no forest food is available for free in the city. What they miss most is bush meat, especially wild boar. In former times, before resettlement, wild boar was always plentiful and free. Any catch was divided up among the whole community. Nowadays, everything costs money. Even wild boar caught by a neighbor or a distant family member is for sale, in violation of customary rules. ${ }^{\text {. }}$

\section{Positive Aspects of Living in the Forest}

The main advantages to living in the forest listed by the Punan of the upper Tubu can be summarized in one statement: "in the forest everything is for free." Food is free $(77 \%)$, land for opening new swiddens is plentiful (65\%), forest products for material (timber, rattan, thatch, etc.) are easily obtained (55\%), forest products for cash (eaglewood, bezoar stones) are available at a short distance $(21 \%)$, and the values of sharing and mutual work are still upheld in the local community (20\%).

\section{Forest products for food}

Salt, sugar, and tobacco are the main items even a self-sufficient family has to buy from the outside. A comparative, quantitative food consumption survey was conducted repeatedly over 15 months in Respen Sembuak and two villages of the upper Tubu. Although average consumption of meat and fish is $86 \mathrm{~g} /$ day/capita near the city, it reaches up to $201 \mathrm{~g} /$ day/capita in the upper Tubu. Wild boar, which is the main source of protein and fat, represents between $47 \%$ and $83 \%$ of the game taken, depending on the season. The average consumption 
of starchy bases does not differ significantly between the two locations: $973 \mathrm{~g} /$ day/capita near Malinau vs. $984 \mathrm{~g} /$ day/capita in remote villages. However, rice represents $87 \%$ of the starchy food consumed in Respen, and only $52 \%$ in remote settlements, where arrow-root, cassava, and wild sago contribute significantly to the diversification of carbohydrate sources and serve as a safety net in case of bad rice harvests. In contrast, there is more diversity of vegetables and condiments in the diet of Punan residing near the city, and the quantities consumed are also greater: 123 g/day/capita in Respen vs. 88 g/day/capita in remote locations. Greater use of vegetables downstream is a consequence of increased gardening among communities that have given up hunting and gathering and have turned to horticulture. The nutritional status appears much better among remote villagers than among those living in and near the city: the body mass index (BMI) for male adults is significantly higher upriver (20.6 vs. 19.9). The average BMI is the same among female adults (19.8), $\mathrm{i}$ but is less subject to fluctuation in the remote communities. We also noted a more frequent occurrence of underweight and overweight subjects among Punan villagers living in or near the city (Dounias et al. unpublished).

\section{Land for swidden cultivation}

In the upper Tubu, the Punan rule over their customary land. They have free access to new swiddens as there are no competing claims by other ethnic groups. The only limitations concern the availability of labor and sufficiently flat tracts of land. The landscape of the upper reaches of the river is mostly hilly, and thus most of the swiddens are established on very steep terrain prone to erosion and heavy leaching of nutrients. Soil fertility problems, combined with a strong incidence of pests, have a significant negative impact on the yield of the swiddens. Rice harvests seldom meet a family's annual needs and must be supplemented by cassava and even sago in bad years.

\section{Forest products for material}

Whatever the basic need, the forest can usually provide for it. Having to pay for timber, as their relatives do in Respen Sembuak, is unthinkable. However, the forest cannot provide iron tools, kitchen equipment, and clothes. Furthermore, even when the forest can provide substitutes, the Punan often prefer manufactured products, e.g., corrugated iron instead of thatch, synthetic ropes instead of rattan, nylon lines and hooks, casting nets, etc.

\section{Forest products for cash}

The forest does not provide manufactured goods such as outboard engines, televisions, and video players, but the collection of marketable forest products does provides the cash to buy them. In the upper Tubu, it came as a surprise that only $21 \%$ of the respondents ranked the availability of forest products for cash among the three top advantages of living in the forest. In other settlements, this figure would have been much higher. In fact, at the time of our survey, the trader controlling the area had virtually stopped operating for almost 4 years, and no other trader was willing to take over such a remote and difficult to access location. In the absence of strong incentives-patron-client debt system, cash advances for collection tourscollectors limit their gathering to short-term sorties in the vicinity of their settlements just to meet their most basic needs: salt, tobacco, and sugar.

\section{Sharing and mutual work}

The values of sharing and mutual work are still upheld in the communities upriver. This positive aspect of living upstream is often mentioned by people who have traveled to visit their relatives in town. There, they were shocked to see that monetary exchanges ruled everywhere, and that nothing was for free. That someone could die only $100 \mathrm{~m}$ from the hospital because their family was unable to come up with enough money to pay for surgery was another shock.

\section{Negative Aspects of Living in the Forest}

Among the negative aspects of living in the forest cited by the people of the upper Tubu, the lack of health care $(67 \%)$, the high price of basic goods $(59 \%)$, poor accessibility (41\%), and the absence of rice mills $(33 \%)$ have already been mentioned. Many respondents $(31 \%)$ also noted the lack of government subsidies. The people upstream consider that they are ignored by the district government and that they do not receive their fair share of the manna annually disbursed at the village level. 


\section{BALANCING TRADE-OFFS}

The trade-offs between conservation and development are illustrated by the dilemma facing the Punan populations living in the forest of the upper Tubu, and those living close to the city of Malinau. In the forest, the Punan are masters of their own home. They can live virtually without cash, as most basic goods are free. The poor, the elderly, and the disabled are taken care of by the community through sharing and mutual aid. The average diet and fitness conditions are significantly better than in town. On the negative side, access to health care and education is very limited. Child and infant mortality rates are high ${ }^{j}$, as are those of illiteracy, especially among women. Manufactured goods are only available at prohibitive costs, and local products are not competitive because of high transportation costs.

In the city, the Punan benefit from all positive aspects of development, including access to both services and goods. Child and infant mortality rates are very low, and illiteracy has been eradicated among the younger generation. Life without electricity, rice mills, transportation, television, video players, and more recently handheld phones is difficult to imagine for the younger generation. Integration is on its way. On the negative side, the Punan complain that nothing in town is free, and that money is needed for everything; even bush meat is no longer shared among neighbors but is sold in the market. The older generation, in particular, resents the loss of Punan culture. Better education does not guarantee a better job. The Punan generally lack the social connections necessary to be recruited as civil servants or company employees. This frustrates young Punan graduates. Because of frustration and unemployment, young people frequently succumb to alcoholism and drug addiction.

Many families consider going back to their ancestral land of the Tubu as a viable option. There, wild boar is plentiful, rivers have an abundance of fish, eaglewood is closer, and land for swiddens is available without major constraints. Furthermore, the forest is still rich in valuable timber that might attract loggers and thus provide income for the community. When asked about the numerous drawbacks (isolation, high price of goods, distance to market, lack of services, etc.), the families argue that moving back upstream does not imply giving up the positive aspects of development. On the contrary, they consider that it is the duty of the government to make such services available even in the remotest settlements.

In the upper Tubu, no families seriously consider moving to town. Some have tried, but gave up after a few weeks. Nobody has the capital required to buy a house and enough land to make a living through agriculture. Nobody has the level of education and training necessary to find off-farm jobs. For most families, living in the forest is the only choice available. But living in the forest does not mean that they reject development. Most Punan Tubu would welcome better infrastructure, schools and dispensaries, access to markets, electricity, rice mills, televisions, and handheld phones.

The Punan do not want to choose between conservation and development, between forest life and city life. They want to benefit from the advantages of both locations, to enjoy both free forest products and the positive aspects of modernity, to go wild boar hunting in the morning and watch television in the evening. In short, they want to enjoy city life in the middle of the forest. The same kind of contradiction is reflected in their identity problems. They want to uphold their identity and carry out the traditional life of huntergatherers, but at the same time, they reject marginalization and seek integration into the larger society. They want integration without loss of identity.

The negative aspects of living in the forest are less linked to the forest's environment than to the area's remoteness. Accessibility is the key problem. Access to health care and education are problematic because it does not make sense for the district government to open schools and dispensaries in small settlements that can only be reached after a 4day trip by boat and on foot. No teacher or paramedic wants to live in such a remote village without any modern facilities. Opening up the forest by providing a better road infrastructure would lower the cost of transportation, thus opening access to the market for local products and lowering the costs of basic commodities. But would it make sense for the district government to build expensive roads across a hilly landscape just to open up access to some small and remote settlements? Obviously, better access would also mean more incentive to clear the forest for timber and for land conversion, more pressure and competition from outsiders, and more of all the other negative features resented by the Punan of Respen Sembuak. 
Fig. 1. Distribution of the Punan population in East-Kalimantan per sub-district. Triangles show the approximate locations of the villages discussed in this paper (RS: Respen Sembuak, UT: Upper Tubu, SP: Sule-Pipa).

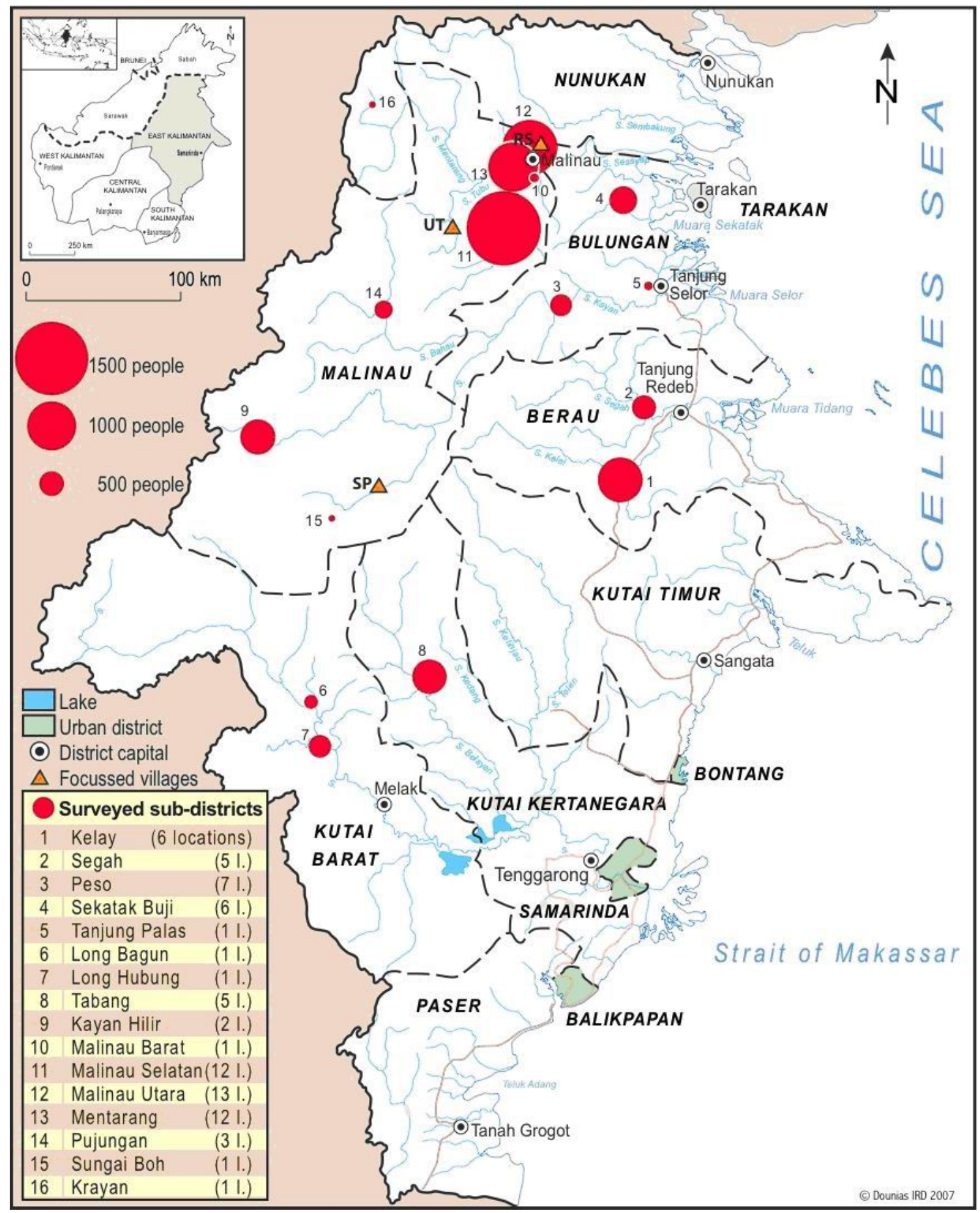


Fig. 2. Child and infant mortality rates (\%).

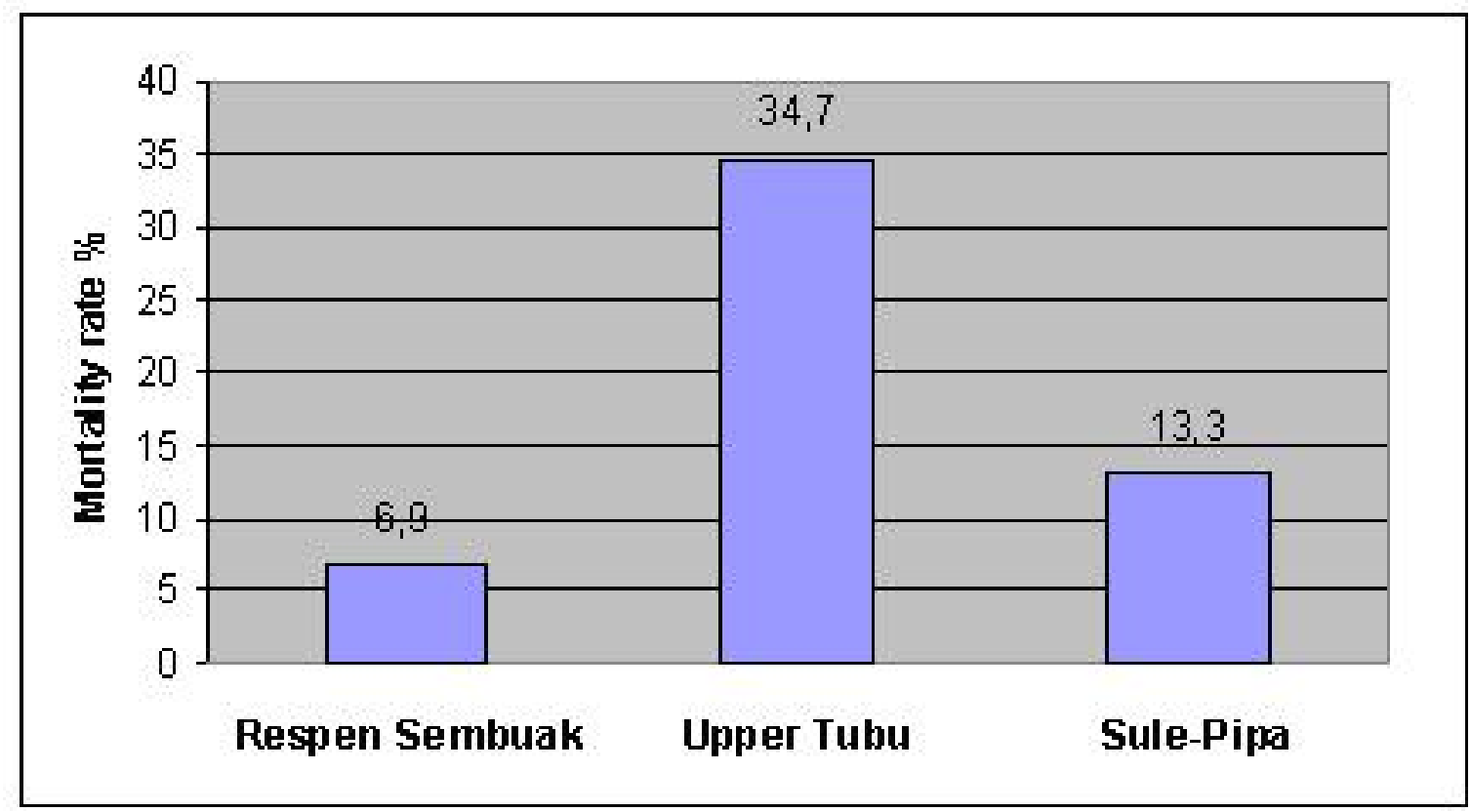

\section{ENJOYING CITY LIFE IN THE MIDDLE OF THE FOREST: THE SULE-PIPA CASE}

The Sule-Pipa settlement in the Apo Kayan provides an example of how people can benefit from most advantages of development without incurring its usual negative aspects. Sule and Pipa are two neighboring resettlement villages located in the Kayan Hilir sub-district (Fig. 1) in the middle of the Apo Kayan. The two villages consist of 152 families or 712 inhabitants (Sitorus et al. 2004). Access by road and then by motor boat is possible, but is difficult and very expensive. The easiest way to access Sule-Pipa is by air. Since 1978, a small airstrip has been in service and is used by a private airline linked to a Christian mission (Missionary Air Fellowship). At least twice daily, the village is in radio contact with Tarakan and Samarinda. The villages boast an equipped dispensary with a paramedic. Furthermore, facilities are offered to villagers who need to go to Samarinda for medical check-ups, and in case of an emergency, a special flight can be scheduled to evacuate the sick. The Sule-Pipa primary school has been established for many decades, and three out of four teachers originate from the community. A secondary school was opened in 2003. Free flights are offered to students to carry on their studies in Samarinda. Access to markets is still difficult, but the strong competition among traders benefits local people. To renew their stocks, traders organize collective road and river transportation in order to reduce costs, or resort to charter flights. The Punan living in Sule and Pipa belong to the Punan Aput group, a group that differs considerably from the Punan Tubu. They are culturally and linguistically distinct and have been integrated in the economic networks of the Kenyah Dayak through friendship and kinship links for about 200 years. The migration of the Dayaks from the Apo Kayan to the Mahakam have left vast empty areas that the Punan Aput use now.

\section{Sanitary Conditions}

The villages of Sule and Pipa are well kept and clean, with clean water conveyance and concrete paths connecting houses. Child and infant mortality rates are surprisingly low considering the remoteness of the settlement (Fig. 2). 
Fig. 3. Level of education.

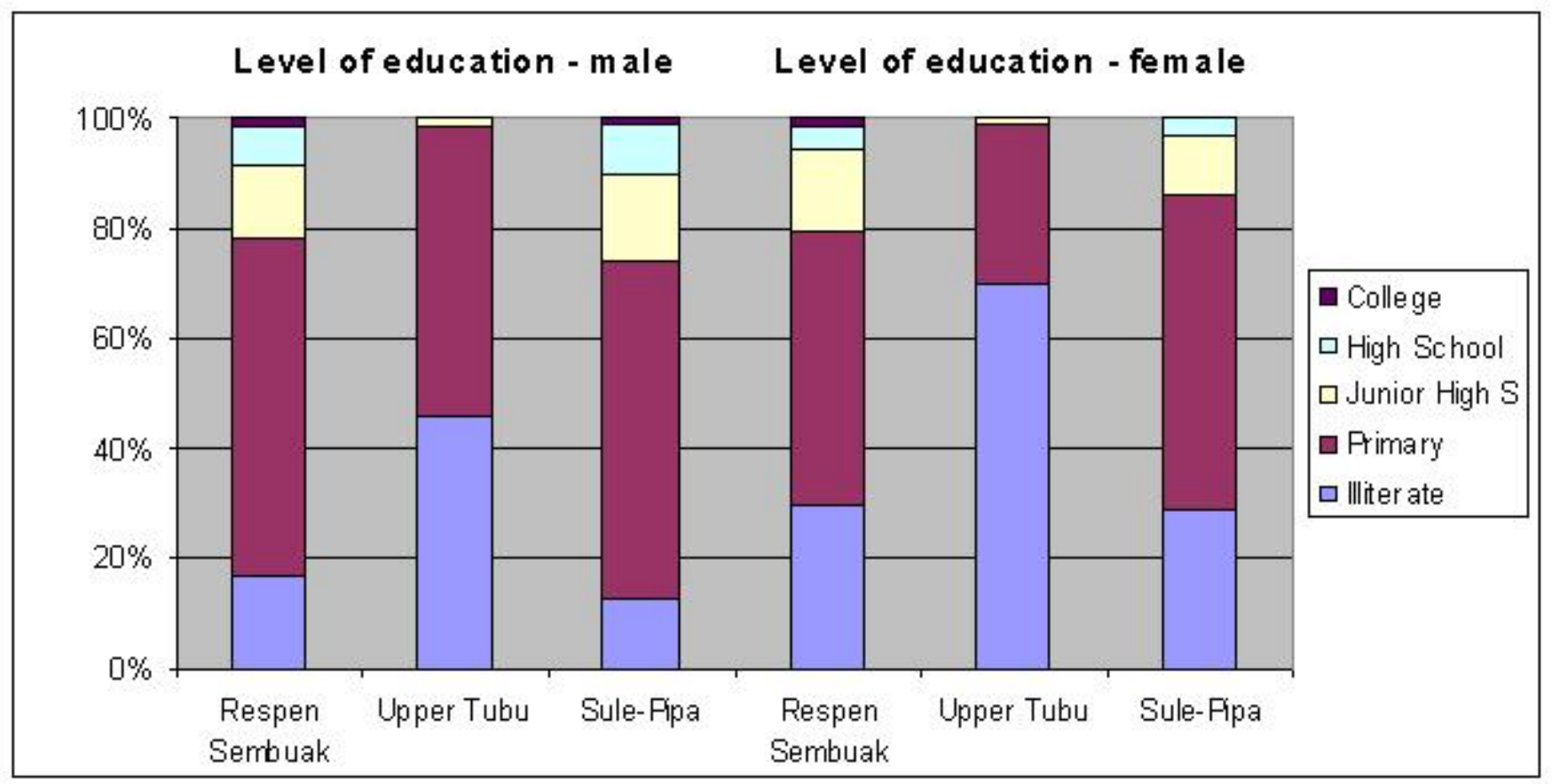

\section{Level of Education}

Compared with Respen Sembuak, the level of education of Sule-Pipa is even slightly better for males, with a lower illiteracy rate and a higher percentage of pupils enrolled in secondary education (Fig. 3). Illiteracy rates for females are not significantly different, but fewer girls continue on to secondary schools. As expected, both locations have better education rates than the upper Tubu.

\section{A Thriving Local Economy}

Sule-Pipa's economy is thriving, essentially because of the collection of forest products. Located in the middle of the vast primary forest of the Apo Kayan, the settlement is the perfect base for collection tours for eaglewood, bezoar stones, and some other minor forest products. Collection of forest products accounts for half of the household income. Quite surprisingly, some wealthier Punan families make more money by helping outsiders collect forest products than by gathering them themselves. Shipping collectors from the village to areas further upstream that are rich in eaglewood, and importing trade items from downstream to the village has become a major source of revenue for boat owners. Considering assets owned, the families of Sule-Pipa appear to be even better equipped than the Punan of Respen Sembuak (Table 3). The average annual household income of Sule-Pipa compares favorably to that of Respen Sembuak (Fig. 4). However, because of their respective locations, income from forest products predominates for the former whereas off-farm activities predominate for the latter. Although the average household income in Respen Sembuak and Sule-Pipa is similar, purchasing powers are quite different. Because of high transportation costs, basic goods are at least twice as expensive in Sule-Pipa and in the upper Tubu than they are in Respen Sembuak. 
Table 3. Assets owned by households (\%)

\begin{tabular}{lccccc}
\hline \hline Settlement & Long-tail engine & Chainsaw & $\begin{array}{c}\text { TV } \\
\text { Parabola }\end{array}$ & $\begin{array}{c}\text { VCD } \\
\text { Player }\end{array}$ & Refrigerator \\
\hline Respen Sembuak & 26 & 9 & 23 & 4 & 1 \\
Hulu Tubu & 8 & 9 & 0 & 0 & 0 \\
Sule-Pipa & 70 & 21 & 14 & 11 & 2 \\
& & & & & \\
\hline
\end{tabular}

\section{DISCUSSION: PREREQUISITES FOR ENJOYING CITY LIFE IN THE FOREST}

Sule-Pipa is the proof that living in the middle of the forest does not necessarily mean living in utter destitution, cut off from all the advantages of development. The Punan Aput may have cultural features that are distinct from those of the Punan Tubu. However, these differences do not preclude any comparison, especially in matters of access to services. Just like the upper Tubu, Sule-Pipa is remote but not isolated. The absence of road infrastructure is key to the site's preservation from intensive logging, from uncontrolled and excessive exploitation of local forest products by outsiders, and from forest conversion. The existence of the airstrip and of regular flights enables access to services such as health care and formal education, and fosters competition among traders.

But securing access to these services brings a high additional cost. Presently, this cost is covered in Sule-Pipa by the Christian mission, thanks to generous donations collected mostly in North America. It should be noted that the role of the Christian mission goes far beyond subsidizing an airline service. The mission exerts a rather strong social control over its flock, which prevents the harmful spending common in Punan environments (alcoholism, gambling, etc.). This cost could also be covered by government subsidies, as occurs, e. g., in French Guyana and in Malaysia with the Penan service centers. Unfortunately, given their current state of development, neither the Indonesian nor the district governments could take on such costs. Certain NGOs might be willing to offer their help. For instance, Médecins du Monde, a French medical
NGO, offered its active help to upgrade district health services in the upper Tubu. Conservation NGOs could also be involved through payments for environmental services (PES). But no matter who the sponsor is, nothing will be possible if the Punan do not agree to gather in permanent settlements ${ }^{\mathrm{k}}$ of a minimum size. No investment in infrastructure can be profitable if the Punan stay in small temporary settlements dispersed over vast areas. A minimum size of 150-200 households is essential to make the settlement attractive to civil servants (teachers, paramedics, administrators) and traders.

Local leadership should preferably be in the hands of the Punan to ensure that they are not overwhelmed and marginalized by more organized ethnic groups. This is not so easy because the Punan, like other hunter-gatherer groups (Woodburn 1982, Testart 1985), have developed a rather egalitarian, sometimes even anarchic, social structure, where respected leaders seldom emerge. Because of their reluctance to accept one of their own as a leader, the Punan often end up following outsiders.

The solutions suggested above to resolve the conservation and development trade-offs, most notably subsidization of remote communities by external agencies, can probably only be considered as transitional. Sooner or later a road will link the remotest villages to the outside world. But playing for time could help the Punan develop capacities and capabilities to compete with other ethnic groups, and thus avoid being marginalized and losing too much of their cultural identity as a result of integration. 
Fig. 4. Average annual household income.

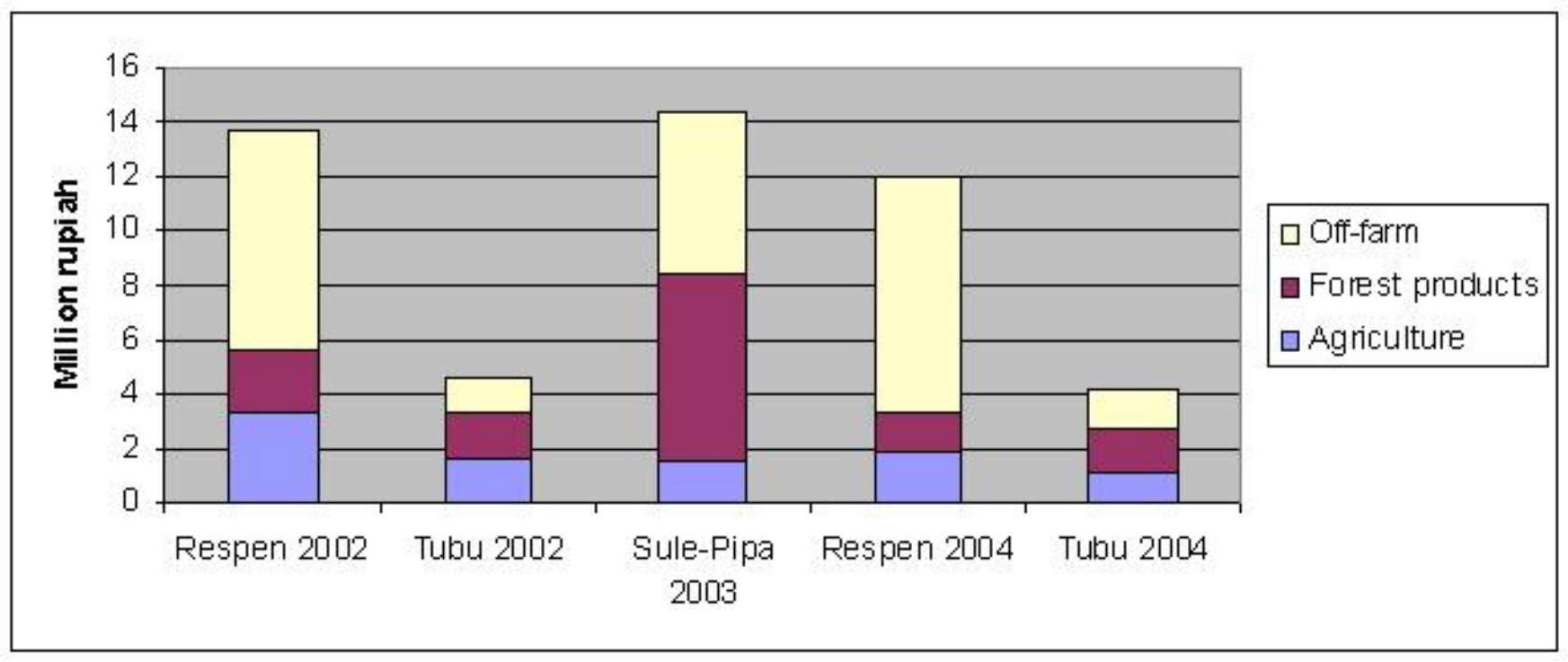

Responses to this article can be read online at: http://www.ecologyandsociety.org/voll2/iss1/art18/responses/

\section{Acknowledgments:}

The authors wish to express their gratitude to Bruce Campbell for the numerous improvements made to the draft version of this paper, as well as to two anonymous referees for their insightful comments.

\section{LITERATURE CITED}

Bunyard, P. 1989. Guardians of the Amazon. New Scientist 35:38-41.

Campbell, B. M., S. Jeffrey, W. Kozanayi, M. Luckert, M. Mutamba, and C. Zindi. 2002. Household livelihoods in semi-arid regions: options and constraints. Center for International Forestry Research, Bogor, Indonesia.

Dounias, E., M. Kishi, A. Selzner, I. Kurniawan, and P. Levang. 2004. No longer nomadic. Changing Punan lifestyle requires new health strategies.
Cultural Survival 28(2):15-19.

Dounias, E., and A. Froment. 2006. When forestbased hunter-gatherers become sedentary: consequences for diet and health. Unasylva 57(2):26-33.

Dounias, E., A. Selzner, M. Koizumi, and P. Levang. 2007. From sago to rice, from forest to town. The consequences of sedentarization on the nutritional ecology of Punan former huntergatherers of Borneo. Food and Nutrition Bulletin 28 (2): in press.

Ellis, F. 2000. Rural livelihood diversity in developing countries. Oxford University Press, Oxford, UK.

Forest Trends. 2002. Strategies for strengthening community property rights over forests: lessons and opportunities for practitioners. Forest Trends, Washington, D.C., USA.

Harrisson, T. 1986. World within. A Borneo story. Oxford University Press, Oxford, UK.

Kaskija, L. 1999. Stuck at the bottom. Opportunity structures and Punan Malinau identity. CIFOR, Bogor, Indonesia. 
Kaskija, L. 2002. Claiming the forest. Punan local histories and recent developments in Bulungan, East Kalimantan. CIFOR, Bogor, Indonesia.

Knapen, H. 1998. Lethal diseases in the history of Borneo. Mortality and the interplay between disease environment and human geography. Pages 69-94 in V. T. King, editor, Environmental challenges in south-east Asia. Curzon Press, Richmond, Surrey, UK.

Levang, P., N. Buyse, S. Sitorus, and E. Dounias. 2005a. Impact de la décentralisation sur la gestion des ressources forestières en Indonésie. Études de cas à; Kalimantan-Est. Anthropologie et Sociétés 29 (1):81-102.

Levang, P., E. Dounias, and S. Sitorus. 2005b. Out of the forest, out of poverty? Forests, Trees and Livelihoods 15:211-235.

Pritchard, B. 2005. Borneo to Broken Hill: how our image of nature affects use. In L. Lester and C. Ellis, editors. Proceedings of Imaging Nature: Media, Environment and Tourism, Cradle Mountain, 27-29 June 2004, University of Tasmania, Hobart, Tasmania, Australia.

Rigg, J. 2006. Land, farming, livelihoods, and poverty: rethinking the links in the rural South. World Development 34(1):180-202.

Sayer, J., and B. Campbell. 2004. The science of sustainable development: local livelihoods and the global environment. Cambridge University Press, Cambridge, UK.

Sellato, B. 2001. Forest, resources, and people in Bulungan. Elements for a history of settlement, trade, and social dynamics in Borneo, 1880-2000. CIFOR, Bogor, Indonesia.

Sheil, D., R. K. Puri, I. Basuki, M. V. Heist, Syaefuddin, Rukmiyati, M. A. Sardjono, I. Samsoedin, K. Sidiyasa, Chrisandini, E. Permana, E. M. Angi, F. Gatzweiler, B. Johnson, and A. Wijaya. 2002. Exploring biological diversity, environment and local people's perspectives in forest landscapes. Methods for a multidisciplinary landscape assessment. CIFOR, Bogor, Indonesia.

Sheil, D., and S. Wunder. 2002. The value of tropical forest to local communities: complications, caveats, and cautions. Conservation Ecology 6(2): 9. (online) URL: http://www.ecologyandsociety.org/ vol6/iss2/art $9 /$.

Sitorus, S., P. Levang, E. Dounias, D. Mamung, and D.Abot. 2004. Potret Punan Kalimantan Timur. CIFOR, Bogor, Indonesia.

Testart,A. 1985. Le communisme primitif. Éditions de la MSH, Paris, France.

Woodburn, J. 1982. Egalitarian societies. Man 17 (3):431-451.

a About 9000 Punan live in the province of East Kalimantan. There are approximately 2000 Punan Tubu scattered among 12 settlements in the district of Malinau (Sitorus et al. 2004).

b Respen Sembuak is composed of ten former villages: eight Punan, one Dayak Abai, and one Dayak Merap. By mid 2005, these ten villages were merged into one village under the authority of a single village head, and the resettlement was renamed Respen Tubu.

${ }^{c}$ Under the initiative of our CIFOR-IRD research program, a joint project between the Médecins du Monde humanitarian organization and the health services of the District of Malinau started in June 2005 by providing basic medical care to the remote villagers of the Tubu watershed three times a year. d Traditional medicine is usually restricted to the curing of (mental) disorders caused by possession by spirits.

e Pills of unknown origin, composition, and effect can be found in any retail shop. Medicines are considered as major trade items by forest product traders.

f "Di hutan terpinggir, di kota tersingkir!" is a common saying among the Punan meaning: isolated in the forest, marginalized in town.

$\mathrm{g}$ The Punan never compete for this kind of job.

$\mathrm{h}$ This example is always given, when Punan are asked to elaborate on what they mean by the weakening of customary rules.

${ }^{i}$ Whatever the location and the season, the BMI of Punan adults stays above 18.5 (standard limit below which nutritionists consider that there is chronic energetic deficiency).

${ }^{\mathrm{j}}$ Higher rates of child mortality upriver (36\% vs. $7 \%$ in urban settlements) is caused by neither malnutrition nor insalubrious life in the forest. It is a direct consequence of increased exposure to transmissible diseases (e.g., smallpox, measles, 
mumps, cholera, rubella, diphtheria, and influenza) in more permanent settlements. The former nomadic lifestyle of the Punan kept them away from diseases. In the new permanent settlements, poor sanitation, bad housekeeping, and increased promiscuity put the children at high risk. Already weakened by constant secondary infection (skin and dental abscesses, chronic otitis), and heavy parasitic loads, they show a total lack of enduring immunity. Isolation, which once protected the Punan from being exposed to these communicable diseases, nowadays only keeps their children away from vaccination campaigns (Dounias and Froment 2006, Dounias et al. 2007).

${ }^{\mathrm{k}}$ For example, the settlement of Long Tuben in the upper Tubu moved three times over a period of 4 years. 